\title{
Assessment of Parkia biglobosa on Hepatic and Renal Biomarkers of Dexamethasone-Exposed Pregnant Rats
}

\author{
Funmilola Comfort Oladele ${ }^{a^{*}}$, Gbenga David Olubunmi ${ }^{b}$, Ruth Odu Odeh ${ }^{\text {b }}$ \\ and Augustine Ikhueoya Airaodion ${ }^{\mathrm{c}}$ \\ ${ }^{a}$ Department of Medical Biochemistry, Ekiti State University, Ado-Ekiti, Nigeria. \\ ${ }^{b}$ Department of Science Laboratory Technology, Ekiti State University, Ado-Ekiti, Nigeria. \\ ${ }^{c}$ Department of Biochemistry, Federal University of Technology, Owerri, Imo State, Nigeria.
}

\begin{abstract}
Authors' contributions
This work was carried out in collaboration among all authors. All authors read and approved the final manuscript.

Article Information

DOI: 10.9734/ARRB/2021/v36i1230471

Editor(s):

(1) Dr. Viduranga Y. Waisundara, Australian College of Business \& Technology, Sri Lanka.

Reviewers:

(1) R. Krishnamurthy, Uka Tarsadia University, India. (2) Geeta Deswal, Guru Gobind Singh College of Pharmacy, India. Complete Peer review History, details of the editor(s), Reviewers and additional Reviewers are available here: https://www.sdiarticle5.com/review-history/78740

Original Research Article

Received 20 October 2021

Accepted 22 December 2021

Published 23 December 2021
\end{abstract}

\begin{abstract}
Aim: This study sought to investigate its effect on hepatic and renal biomarkers of female pregnant rats.

Place and Duration: This work was carried out in the Department of Medical Biochemistry and Department of Science Laboratory Technology, Ekiti State University, Ado Ekiti between January and June 2021.

Methodology: Locust bean seeds were purchased from an open market in Ado Ekiti, Nigeria and were processed using standard method. Fifteen female pregnant rats were divided into three groups of five each. Animals in group A were exposed to standard animal feed only. This served as the control group. Those in group B were exposed to animal feed mixed with locust beans $+0.3 \mathrm{mg} / \mathrm{kg}$ body weight of dexamethasone, while those in group $C$ were exposed to animal feed mixed with locust beans only. At the end of the eight days treatment, animals were sacrificed and blood sample, liver and kidney were collected.

Results: Exposure of pregnant rats to dexamethasone was observed to significantly $(p<0.05)$ increased the activities of plasma aspartate amino transaminase (AST) and alanine amino transferase (ALT) as well as the concentrations of plasma total protein, bilirubin, creatinine and urea
\end{abstract}


when compared with those in animals in the control as well as those treated with $P$. biglobosa only. The results further showed that administration of $P$. biglobosa only had no significant effect on plasma hepatic and renal biomarkers except urea which was significantly lower than those in the control group as well as those treated with dexamethasone. The results obtained from liver and kidney homogenate respectively are similar to those observed in the plasma.

Conclusion: Exposure of animals to dexamethasone adversely unhinged hepatic and renal biomarkers investigated in the study. The study also revealed that $P$. biglobosa seed is beneficial to the health of the liver and kidney of pregnant female rats.

Keywords: Dexamethasone; Pregnancy; Parkia biglobosa; Liver; Kidney.

\section{INTRODUCTION}

Liver is the major organ which plays key roles in processing critical biochemical and physiological phenomena including metabolism and detoxification of endogenous and exogenous compounds, such as drugs and xenobiotics, homeostasis, growth, energy and nutrient supply [1]. Hepatic injury could occur by hepatotoxic agents such as drugs, alcohol, hydrocarbon and viral infections [2]. Liver diseases like jaundice, cirrhosis and fatty liver have been public health concern across the world [3]. Prevalence of chronic liver disease worldwide is $18.5 \%$ and cirrhosis is 4.5 to $9.5 \%$ while 2 million people die each year. In terms of medication, conventional or synthetic drugs are limited. Moreover they can have serious side effects $[4,5]$. Due to this fact, a huge number of medicinal plants have been used to figure out hepato-protective activities [6]. Approximately 160 phytochemical constituents originated from 101 plants have been reported to be potentially hepato-protective [7]. At present, medicinal plants have been a vital source of treatment of liver [8].

Nephrotoxicity can be defined as the adverse effect of substances on renal function [9]. These substances can include molds and fungi, cancer therapeutics such as cisplatin, antibiotics such as aminoglycosides, metals such as mercury, arsenic and lead, and drugs of abuse such as cocaine. One indication of nephrotoxicity is a change in renal function as assessed by the glomerular filtration rate (GFR), blood urea nitrogen (BUN), serum creatinine $(\mathrm{sCr})$, or bilirubin concentrations; however, nephrotoxicants can induce kidney damage without changing any established clinical marker of renal function. For example, studies have shown that proximal tubule necrosis in male Sprague Dawley rats exposed to gentamicin can be as high as $75 \%$ prior to any increases in BUN or $\mathrm{sCr}[10]$.
Parkia biglobosa (locust bean) has long been widely recognized as an important indigenous multipurpose fruit tree whose uses include food, medicine, manure, tannin, shade, wind breaks, bee food, stabilization of degraded environment, livestock feed, fuel, fibre, fish poison and several other domestic uses [11]. Parkia biglobosa has many medicinal uses in Africa [12]. It provides an ingredient that is used in treating leprosy and hypertension [13]. It has been identified as one of the candidates with promising therapeutic potential in the prevention, treatment, and management of a number of metabolic diseases including diabetes mellitus [14]. According to Tokoudagba et al. [15], $P$. biglobosa leaf extracts induce redox-sensitive endothelium-dependent relaxations in porcine coronary artery rings thereby acting as an antihypertensive agent. The leaves are used in lotions for sore eyes, burns, haemorrhoids and toothache [12]. A decoction of the leaves, bark and roots are used in treating leprosy, eye sores, toothache, fever, hypertension, wounds and ulcers [16]. Airaodion et al. [17], has reported that $P$. biglobosa seed possesses hepatoprotective ability. In another study, Airaodion and Ogbuagu [18] observed that $P$. biglobosa seed ameliorated hypertension. This study sought to investigate its effect on hepatic and renal biomarkers of female pregnant rats.

\section{METHODS}

\subsection{Collection and Preparation of Materials}

Locust bean seeds were purchased from an open market in Ado Ekiti, Nigeria. They were authenticated by the Chief botanist of the Department of Plant Science, Ekiti State University, Ado-Ekiti and deposited in the University's Herbarium with Voucher number UHAE-2020063. They were selected for any possible dirt and was rinsed thoroughly with 
water, after which, they were soaked in a cold water for about 15 minutes and boiled in a pressure pot for 2 hours, followed by de-hulling and stepping/matching on the boiled locust beans and washing with cold water, it was rewashed and cooked for 45 minutes to make it softer and rinsed using a plastic sieve. It was fermented to produce the food condiment which is used as soup seasoning/spices (flavoring agent). This was done by spreading the boiled locust beans into a fermenting can and wrapped with cloth for 48 hours to prevent oxygen. Subsequently, the fermented $P$. biglobosa seeds were air dried for 3 days and was milled into powder using an electric blender and stored for further analysis.

\subsection{Experimental Design}

The use of animals for this study was approved by the Experimental Animal Research Ethics Committee of Ekiti State University, Ado-Ekiti with ethical approval number ORD/ETHICS/AD/043. Twenty one Albino rats (6 males and 15 females) were obtained from the Animal House, Faculty of Basic Medical Sciences, College of Medicine, Ekiti State University, Ado-Ekiti. They were grouped into three of 2 males and 5 females in each group using plastic cages with steel wire lids to copulate, since the experiment requires the female Albino rats to be pregnant. They were kept at room temperature with adequate access to rat chow and water throughout the experimental period. After a week of copulation, all the female Albino rats were confirmed pregnant by the animal house technician. The males rats were removed from their cages and the female pregnant rats were treated as follows: animals in group A were exposed to standard animals feed only. This served as the control group. Those in group B were exposed to animal feed mixed with locust beans $+0.3 \mathrm{mg} / \mathrm{kg}$ body weight of dexamethasone, while those in group $\mathrm{C}$ were exposed to animal feed mixed with locust beans. At the end of the eight days treatment, animals were sacrificed and blood sample was collected into EDTA bottles and centrifuged. Plasma was separated and preserved at $4{ }^{\circ} \mathrm{C}$ for further analysis. Liver and kidney were also harvested from the rats and were homogenized in phosphate water using a mechanical homogenizer and the homogenates were centrifuged for 5 minutes. The supernatant were collected and were used to carry out the biochemical assays.

\subsection{Determination of Biochemical Parameters}

Aspartate Aminotransferase (AST) and Alanine Aminotransferase (ALT) activities were determined using Randox commercial Enzyme kits according to the method of Reitman and Frankel [19]. Total Protein concentration was carried out using Biuret method described by Henry et al. [20]. Estimation of albumin was done by bromocresol green (BCG) method described by Doumas et al. [21]. Bilirubin concentration was determined by diazo method described by Royden and Alfred [22]. Creatinine concentration was determined using Jaffe reaction described by Toora and Rejagopal [23]. Urea concentration was determined using a Randox Commercial Kit based on the methods of Fesus et al. [24]. The concentrations of total protein and albumin were determined using Biorex diagnostic kit according to the methods of Lorentz [25].

\subsection{Statistical Analysis}

Data were subjected to analysis of variance using Graph Pad Prism. Results were presented as Mean \pm Standard deviation. One way analysis of variance (ANOVA) was used for comparison of the means followed by Tukey's post hoc test. Differences between means were considered to be significant at $p<0.05$.

\section{RESULTS}

Exposure of pregnant rats to dexamethasone was observed to significantly $(p<0.05)$ increased the activities of plasma aspartate amino transaminase (AST) and alanine amino transferase (ALT) as well as the concentrations of plasma total protein, bilirubin, creatinine and urea when compared with those in animals in the control as well as those treated with $P$. biglobosa only (Table 1). The results further showed that administration of $P$. biglobosa only had no significant effect on plasma hepatic and renal biomarkers except urea which was significantly lower than those in the control group as well as those treated with dexamethasone. Tables 2 and 3 contained the results from liver and kidney homogenate respectively. The results are similar to those observed in the plasma.

\section{DISCUSSION}

Every organ can elicit a specific pattern of enzyme release, which has not been elucidated. Specifically, above-normal plasma enzyme 
activities are considered as diagnostic features for several diseases [26]. Liver tissue damage due to toxic compounds is associated with its detoxification function [27]. The results of plasma hepatic and renal parameters determined in this study are presented in Table 1 .

The activity of AST in dexamethasone-treated rats was observed to be significantly $(P<0.05)$ higher when compared with those in the control group as well as those treated with $P$. biglobosa only. This increase might be an indication of hepatotoxic effect of dexamethasone as AST is a biomarker enzyme found to be abundant in cases where the liver might be damage [28,29].

Similarly, the activity of ALT was significantly $(p<0.05)$ increased in animals exposed to dexamethasone when compared with those in control animals as well as the group treated with $P$. biglobosa only. The distribution and relative tissue concentration of ALT is similar but importantly different. Highest activity is found in the liver, followed by kidney, myocardium, skeletal muscle, pancreas, spleen, lung, and erythrocyte [30]. ALT activity is found in the cytosol, unlike AST which is both cytosolic $(20 \%$ of total activity) and mitochondrial ( $80 \%$ of total activity) [28,31]. Release of mitochondrial enzymes from the liver is considered to provide strong evidence for hepatic necrosis [32]. AST is also found in other organs such as the heart and skeletal muscle, while ALT has low concentrations in the skeletal muscle and kidney, and is chiefly produced in the hepatocytes $[31,33]$. Release of liver mitochondrial enzymes is considered as a strong evidence for hepatic necrosis, which is associated with an increased production of Reactive Oxygen Species (ROS), often leading to greater hepatic lipid peroxidation [34]. It was also observed that treatment of animals with $P$. biglobosa only had no significant effect on liver enzymes assayed in this study. This result conformed to the findings of Airaodion et al. [17] who reported that $P$. biglobosa possessed hepatoprotective propensity.

In this study, a significant increase was observed in the concentrations of total protein and albumin in dexamethasone-treated animals when compared with those in control animals as well as those in the group exposed to $P$. biglobosa only. This might suggest that dexamethasone has affected the synthetic ability of protein by the liver. It is also an indication that dexamethasone distorted the functional activity of the liver by interfering with the equilibrium in the rate of synthesis and destruction, removal or clearance of total protein and albumin from the system of the animals [35]. Increase in total protein has

Table 1. Effect of P. biglobosa on plasma hepatic and renal biomarkers of dexamethasonetreated pregnant rats

\begin{tabular}{|c|c|c|c|}
\hline Parameters & Control & Dexamethasone + P. biglobosa & $P$. biglobosa only \\
\hline AST (U/L) & $46.75 \pm 1.16^{b}$ & $63.88 \pm 2.21^{\mathrm{a}}$ & $47.32 \pm 2.29^{b}$ \\
\hline $\operatorname{ALT}(\mathrm{U} / \mathrm{L})$ & $38.21 \pm 3.07^{b}$ & $48.28 \pm 3.12^{a}$ & $37.10 \pm 1.83^{b}$ \\
\hline Total Protein (mmol/L) & $49.95 \pm 1.92^{b}$ & $64.85 \pm 2.51^{\mathrm{a}}$ & $46.02 \pm 3.40^{b}$ \\
\hline Albumin $(\mathrm{mmol} / \mathrm{L})$ & $28.38 \pm 0.89^{b}$ & $37.50 \pm 2.43^{\mathrm{a}}$ & $26.11 \pm 1.31^{\mathrm{b}}$ \\
\hline Bilirubin (mmol/L) & $83.73 \pm 1.56^{\mathrm{b}}$ & $101.12 \pm 4.45^{\mathrm{a}}$ & $81.15 \pm 5.03^{b}$ \\
\hline Creatinine $(\mathrm{mmol} / \mathrm{L})$ & $44.26 \pm 1.74^{b}$ & $67.42 \pm 2.00^{a}$ & $43.02 \pm 1.04^{b}$ \\
\hline Urea $(\mathrm{mg} / \mathrm{dL})$ & $6.22 \pm 0.92^{b}$ & $8.76 \pm 1.27^{\mathrm{a}}$ & $5.08 \pm 0.63^{c}$ \\
\hline
\end{tabular}

Table 2. Effect of $\boldsymbol{P}$. biglobosa on the hepatic biomarkers of liver-homogenate of dexamethasone-treated pregnant rats

\begin{tabular}{|c|c|c|c|c|}
\hline Treatment Group & AST (U/L) & ALT (U/L) & $\begin{array}{l}\text { Total Protein } \\
\text { (mmol/L) }\end{array}$ & $\begin{array}{l}\text { Albumin } \\
\text { (mmol/L) }\end{array}$ \\
\hline $\begin{array}{l}\text { Control } \\
\text { Dexamethasone }+P \text {. biglobosa } \\
P \text {. biglobosa only }\end{array}$ & $\begin{array}{l}47.20 \pm 1.47^{b} \\
57.56 \pm 0.63^{a} \\
42.44 \pm 3.13^{b}\end{array}$ & $\begin{array}{l}34.29 \pm 0.88^{b} \\
46.90 \pm 1.58^{a} \\
45.23 \pm 1.28^{b}\end{array}$ & $\begin{array}{l}73.58 \pm 1.92^{b} \\
85.78 \pm 2.64^{a} \\
69.63 \pm 0.83^{b}\end{array}$ & $\begin{array}{l}15.99 \pm 1.82^{b} \\
28.03 \pm 4.09^{a} \\
17.37 \pm 1.54^{b}\end{array}$ \\
\hline
\end{tabular}



Table 3. Effect of $\boldsymbol{P}$. biglobosa on the renal biomarkers of kidney-homogenate of
dexamethasone-treated pregnant rats

\begin{tabular}{llll}
\hline Treatment Group & $\begin{array}{l}\text { Total Protein } \\
(\mathbf{m m o l} / \mathbf{L})\end{array}$ & $\begin{array}{l}\text { Urea } \\
(\mathbf{m g} / \mathbf{d L})\end{array}$ & $\begin{array}{l}\text { Creatinine } \\
(\mathbf{m m o l} / \mathbf{L})\end{array}$ \\
\hline Control & $19.67 \pm 2.20^{\mathrm{b}}$ & $51.87 \pm 1.41^{\mathrm{b}}$ & $54.23 \pm 1.73^{\mathbf{b}}$ \\
Dexamethasone + P. biglobosa & $25.18 \pm 1.12^{\mathrm{a}}$ & $66.46 \pm 1.93^{\mathrm{a}}$ & $67.62 \pm 1.79^{\mathrm{a}}$ \\
P. biglobosa only & $17.44 \pm 3.44^{\mathbf{b}}$ & $53.53 \pm 1.13$ & $55.04 \pm 2.57^{\mathbf{b}}$ \\
\hline Results are presented as mean+standard deviation with $n=5$. Values with different superscripts along the same $^{2}$
\end{tabular}
row are significantly different at $P<0.05$

been reported to lead to dehydration which is detrimental to cellular homeostasis [36] which negatively affects the metabolic activities of the liver and consequently the health of the animals. Albumin binds and transports metal ions, bilirubin, and drugs. Its level is used to assess the synthetic function of the liver. Plasma protein levels are regulated via synthesis in the liver and its levels thus reflect the synthetic ability of the liver. Therefore, the result of this study is an indication that dexamethasone compromised the integrity of the liver.

Bilirubin is the breakdown product of heme moiety of hemeoglobin; other hemeoproteins include cytochromes, catalase, peroxidase, tryptophan pyrrolase and a small pool of free heme [37]. Increase in concentration of bilirubin in blood causes hyperbilirubinaemia, which is toxic under certain conditions inducing jaundice, hyperbilirubinemia-induced auditory dysfunction and neurotoxicity resulting in brain damage [38]. Plasma bilirubin levels are often enhanced under a variety of clinical conditions. In the circulation of blood, bilirubin is bound to plasma albumin, which prevents its potential toxicity thought to be caused by free bilirubin [39]. Despite its high affinity of binding to albumin, bilirubin is rapidly and selectively taken up by the liver, biotransformed upon conjugation with glucuronate, and secreted into bile [40]. Thus bilirubin is converted into bilirubin glucuronic acid in the liver and excreted along with bile. The nonsignificant difference observed in the concentrations of hepatic biomarkers in animals treated with $P$. biglobosa only when compared with those in the control group in this study suggests that the $P$. biglobosa did not cause liver damage. This observation affirms the hepatoprotective ability of $P$. biglobosa reported earlier reported by Airaodion et al. [17].

Dexamethasone used in this study significantly $(p<0.05)$ increased the concentrations of creatinine and urea in both plasma and kidney homogenate when compared with those of animals in the control group as well as those treated with $P$. biglobosa only. Urea is a major nitrogenous end product of protein and amino acid catabolism and creatinine is a breakdown product of creatinine phosphate in the muscle [41]. They are excreted by the kidney. The significant rise in the concentrations of creatinine and urea in plasma and kidney homogenate observed in this study most probably represents increased production of both creatinine and urea to meet the energy demand following severe oxidative stress caused by dexamethasone.

Urea and creatinine are good indicators of a normal functioning kidney and increase in the plasma could also be indications of kidney dysfunction as they are widely accepted and commonest parameters to assess renal functions [42]. These results suggest that kidney functions were seriously impaired by dexamethasone exposure. This may increase the incidence of chronic kidney disease arising from nephrotoxicity of dexamethasone and its ability to damage the kidney. The effect of $P$. biglobosa in animals treated with $P$. biglobosa only when compared with those in the control group suggests that the $P$. biglobosa did not cause damage, and thus could be nephron-protective.

\section{CONCLUSION}

Exposure of animals to dexamethasone adversely unhinged hepatic and renal biomarkers investigated in this study. The study also revealed that $P$. biglobosa seed is beneficial to the health of the liver and kidney of pregnant female rats.

\section{DISCLAIMER}

The products used for this research are commonly and predominantly use products in our area of research and country. There is absolutely no conflict of interest between the authors and producers of the products because we do not intend to use these products as an avenue for 
any litigation but for the advancement of knowledge. Also, the research was not funded by the producing company rather it was funded by personal efforts of the authors.

\section{CONSENT}

It is not applicable.

\section{ETHICAL APPROVAL}

The use of animals for this study was approved by the Experimental Animal Research Ethics Committee of Ekiti State University, Ado-Ekiti with ethical approval number ORD/ETHICS/AD/043.

\section{COMPETING INTERESTS}

Authors have declared that no competing interests exist.

\section{REFERENCES}

1. Mahmood DN, Mamat SS, Kamisan HF, Yahya F, Kamarolzaman FFM, Nasir N , Mohtarrudin N, Tohid, and Zakaria AZ. Amelioration of Paracetamol-Induced Hepatotoxicity in Rat by the Administration of Methanol Extract of Muntingia calabura L. Leaves. Bio Med Research International. $2014,1-10$.

2. Airaodion Al, Ogbuagu U, Ekenjoku JA, Ogbuagu EO, Airaodion EO, Okoroukwu VN. Hepato-protective efficiency of ethanol leaf extract of Moringa oleifera against hydrocarbon exposure. International Journal of advances in Herbal and Alternative Medicine. 2019;03(01):32-41.

3. Airaodion Al, Ogbuagu EO. Effect of Cyperus esculentus L. (tiger nut) milk on hepatic and renal indices of Wistar rat. Asian Journal of Research in Nephrology. 2020;3(2):10-16.

4. Airaodion Al, Megwas AU, Ekenjoku JA, Ngwogu KO, Ngwogu AC. Nephro- and hepato-toxicity of common household insecticides used in Nigeria. International Research Journal of Gastroenterology and Hepatology. 2020;3(2):21-28.

5. Airaodion Al, Alabi OJ, Ogbuagu EO, Atiba FA, Olawoyin DS. Nephro and hepatotoxic effect of air-freshener in Wistar rats. Asian Journal of Research in Nephrology. 2020;3(2):1-9.

6. Airaodion $\mathrm{Al}$, Ogbuagu EO, Ekenjoku JA, Ogbuagu U, Airaodion EO. Therapeutic effect of methanolic extract of Telfairia occidentalis leaves against acute ethanolinduced oxidative stress in Wistar rats. International Journal of Bio-Science and Bio-Technology. 2019;11(7):179-189.

7. Chatterjee TK. Medicinal plants with hepatoprotective properties, in Herbal Opinions, third ed. Books \& Allied (P) Ltd., Calcutta. 2000;135.

8. Airaodion Al, Akinmolayan JD, Ogbuagu EO, Esonu CE, Ogbuagu U. Preventive and therapeutic activities of methanolic extract of Talinum triangulare leaves against ethanol-induced oxidative stress in Wistar rats. International Journal of BioScience and Bio-Technology. 2019;11(7):85-96.

9. Perazella M. Renal vulnerability to drug toxicity. Clin. J. Am. Soc. Nephrol. 2009;4, 1275-1283.

10. Zhou Y, Vaidya VS, Brown RP, Zhang J, Rosenzweig BA, Thompson KL, Miller TJ, Bonventre JV, Goering PL. Comparison of kidney injury molecule-1 and other nephrotoxicity biomarkers in urine and kidney following acute exposure to gentamicin, mercury, and chromium. Toxicol. Sci. 2008;101, 159-170.

11. Sadiku OA. Processing Methods Influence the Quality of Fermented African Locust Bean (Iru/ogiri/dawadawa) Parkia biglobosa. Publisher: Journal of Applied Sciences Research, Ibadan, Nigeria. 2010;1.

12. Udobi CE, Onaolapo JA. Bioactive Compounds of the stem bark of Parkia biglobosa. J Appl Pharm Sci 2012; 02(07): 133-137.

13. Odetola AA, Akinloye O, Egunjobi C, Adekunle WA, Ayoola AO. Possible antidiabetic and antihyperlipidaemic effect of fermented Parkia biglobosa (Jacq) extract in alloxan-induced diabetic rats. Clin Exp Pharmacol Physiol. 2006;33:808812.

Available:https://doi.org/10.1111/j.1440-

1681.2006.04444.x

14. Airaodion Al, Airaodion EO, Ogbuagu EO, Ogbuagu U, Osemwowa EU. Effect of Oral Intake of African Locust Bean on Fasting Blood Sugar and Lipid Profile of Albino Rats. Asian Journal of Research in Biochemistry. 2019;4(4): 1-9.

15. Tokoudagba J, Auger C, Bréant L, N'Gom S, Chabert P, Idris-Khodja N, Gba-guidi F, Gbenou J, Moudachirou M, Lobstein A. Procyanidin-rich fractions from Parkia 
biglobosa (Mimosaceae) leaves cause redox-sensitive endotheliumde -pendent relaxation involving $\mathrm{NO}$ and EDHF in porcine coronary artery. J Ethnopharmacol. 2010;132(1):246-250.

16. El-Mahmood AM, Ameh JM. In vitro antibacterial activity of Parkia biglobosa (Jacq.) root bark extract against some microorganisms associated with urinary tract infections. Afr J Biotechnol. 2007; 6(11):1272-1275.

17. Airaodion Al, Ogbuagu EO, Ogbuagu U, Adeniji AR, Agunbiade AP, and Airaodion EO. Hepatoprotective effect of Parkia biglobosa on acute ethanol-induced oxidative stress in Wistar rats. International Research Journal of Gastroenterology and Hepatology. 2019;2(1):1-11.

18. Airaodion Al, Ogbuagu EO. Ameliorative effect of Parkia biglobosa (African locust bean) against egg-yolk induced hypertension. International Journal of BioScience and Bio-Technology. 2020; 12(5):17-25.

19. Reitman S, Frankel S. A colorimetric method for determination of serum glutamate oxaloacetate and glutamic pyruvate transaminase. American Journal of Clinical Pathology. 1957;28:56-58.

20. Henry RJ, Sobel C, Berkman S. Interferences with biuret methods for serum proteins. Anal. Chem. 1974;29:1491-1495.

21. Doumas BT, Watson WA, Biggs HG. Albumin standards and the measurement of serum albumin with BCG. Clin Chim Acta. 1971;31: 87-96.

22. Royden NR, Alfred P. A New Diazo Method for the Determination of Bilirubin. Clinical Chemistry. 1962;8(6):570-578.

23. Toora BD, Rejagopal G. Measurement of creatinine concentration by Jaffe's Reaction. Indian Journal of Experimental Biology. 2002;40(3):352 - 354.

24. Fesus PD, Pressac M, Braconnier $F$, Aymard P. Automated determination of urinary $\mathrm{Na}, \mathrm{K}$, inorganic phosphate, urea, and creatunine without sample dilution, with the RA-XT. Cliii Chem. 1983;35:481483.

25. Lorentz K. Lipase. In: Thomas L, editor. Clinical laboratory diagnostics. 1st ed. Frankfurt: TH-Books Verlagsgesellschaft. 1998; pp95-97.

26. Verrill HL, Pickard NA, Gruemer HD. Mechanisms of cellular enzyme release. I. Alteration in membrane fluidity and permeability. Clinical Chemistry. 1997;23 (12):2219-2225.

27. Airaodion Al, Ogbuagu EO, Ewa O, Ogbuagu U, Awosanya OO, Adekale OA. Ameliorative efficacy of methanolic extract of Corchorus olitorius leaves against acute ethanol-induced oxidative stress in Wistar rats. Asian Journal of Biochemistry, Genetics and Molecular Biology. 2019; 7(6):1-9.

28. Vroon $\mathrm{DH}$, Israili Z. Aminotransferases. In: Walker HK, Hall WD, Hurst JW, editors. Clinical Methods: The History, Physical, and Laboratory Examinations. 3rd edition. Boston: Butterworths; 1990. Chapter 99. Available:https://www.ncbi.nlm.nih.gov/boo ks/NBK425/

29. Airaodion Al, Akunne PN, Njoku OC, Oladosu NO, Megwas AU. Effect of Bambara nut on hepatic biomarkers of Wistar rats. International Research Journal of Gastroenterology and Hepatology. 2021;4(2):1-8.

30. Airaodion AI, Akinmolayan JD, Ogbuagu EO, Esonu CE, Ogbuagu U. Preventive and therapeutic activities of methanolic extract of Talinum triangulare leaves against ethanol-induced oxidative stress in Wistar rats. International Journal of BioScience and Bio-Technology. 2019;11(7):85-96.

31. Ogbuagu EO, Airaodion Al, Ogbuagu U, Airaodion EO. Prophylactic propensity of methanolic extract of Vernonia amygdalina leaves against acute ethanol-induced oxidative stress in Wistar rats. International Journal of Bio-Science and BioTechnology. 2019;11(7):37-46.

32. Airaodion Al, Ngwogu AC, Ekenjoku JA, Ngwogu KO. Hepatoprotective potency of ethanolic extract of Garcinia kola (Heckel) seed against acute ethanol induced oxidative stress in Wistar rats. International Research Journal of Gastroenterology and Hepatology. 2020;3(2):1-10

33. Kumar J, Lind L, Salihovi S. Persistent organic pollutants and liver dysfunction biomarkers in a population-based human sample of men and women. Environmental Research. 2014;134:251-256.

34. Martha LC, Hernández-Muñoz R. Is Liver Enzyme Release Really Associated with Cell Necrosis Induced by Oxidant Stress?;2016.

Available:https://doi.org/10.1155/2016/352 9149 
35. Bashir L, Shittu OK, Busari MB, Sani S, Aisha MI. Safety evaluation of giant African land snails (Archachatina maginata) haemolymph on hematological and biochemical parameters of Albino rats. J Adv Med Pharm Sci. 2015;3(3):122130.

36. Shittu OK, Lawal B, Alozieuwa BU, Haruna GM, Abubakar AN, Berinyuy EB. Alteration in biochemical indices following chronic administration of methanolic extract of Nigeria bee Propolis in Wistar rats. Asian Pac J Trop Dis. 2015;5(8):654-657.

37. Ogbuagu EO, Airaodion Al, Ogbuagu U, Nweke IN, Unekwe PC. Nephrotoxicity of ethanol extract of Xylopia aethiopica fruit in Wistar rats. International Journal of Advances in Nephrology Research. 2021; 4(1):1-16.

38. Shapiro SM. Bilirubin toxicity in the developing nervous system. Pediatr neurol., 2003;29:410-421.
39. Airaodion Al, Ngwogu KO, Ngwogu AC, Megwas AU, Ekenjoku JA. Nephrotoxicity of monosodium glutamate (MSG) in Wistar rats. International Journal of Advances in Nephrology Research. 2020;3(1):1-10.

40. Perlstein TS, Pande RL, Creager MA, Weuve J, Beckman JA. Serum total bilirubin level, prevalent stroke, and stroke outcomes: NHANES 1999-2004. American Journal of Medicine. 2008;121:781-788.

41. Kamal A. Estimation of blood urea (BUN) and serum creatinine level in patients of renal disorder. IJFALS. 2014;4 (4):199202.

42. Airaodion Al, Ene AC, Ogbuagu EO, Okoroukwu VN, Ekenjoku JA, Ogbuagu U. Biochemical changes associated with consumption (by rats) of "garri" processed by traditional and instant mechanical methods. Asian Journal of Biochemistry, Genetics and Molecular Biology. 2019;2 (4):1-11.

(0) 2021 Oladele et al.; This is an Open Access article distributed under the terms of the Creative Commons Attribution License (http://creativecommons.org/licenses/by/4.0), which permits unrestricted use, distribution, and reproduction in any medium, provided the original work is properly cited.

Peer-review history:

The peer review history for this paper can be accessed here: https://www.sdiarticle5.com/review-history/78740 